\title{
Appendix A: Licences issued for Icelandic harbours
}

Abbreviations: Y: Number of years; a.g.: ad gratiam, i.e. until further notice.

Dates and places between square brackets are not mentioned in the licence, but have been reconstructed from other sources.

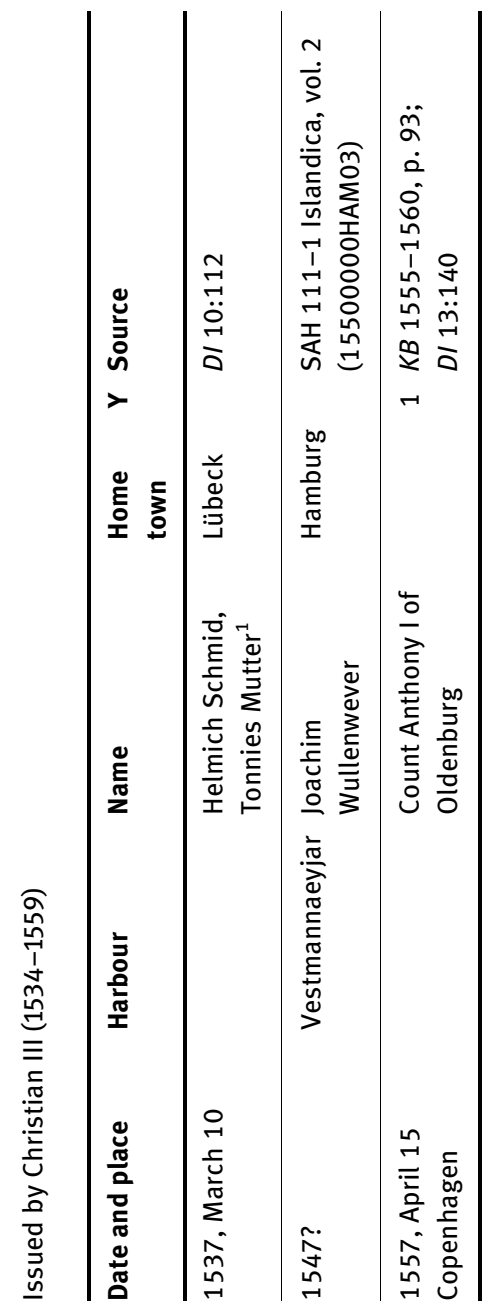

1 On the "kravel" of Herman Vurborn.

Ә Open Access. (C 2020 Bart Holterman, published by De Gruyter. (cc) BY-NC-ND This work is licensed under a Creative Commons Attribution-NonCommercial-NoDerivatives 4.0 International License.

https://doi.org/10.1515/9783110655575-011 


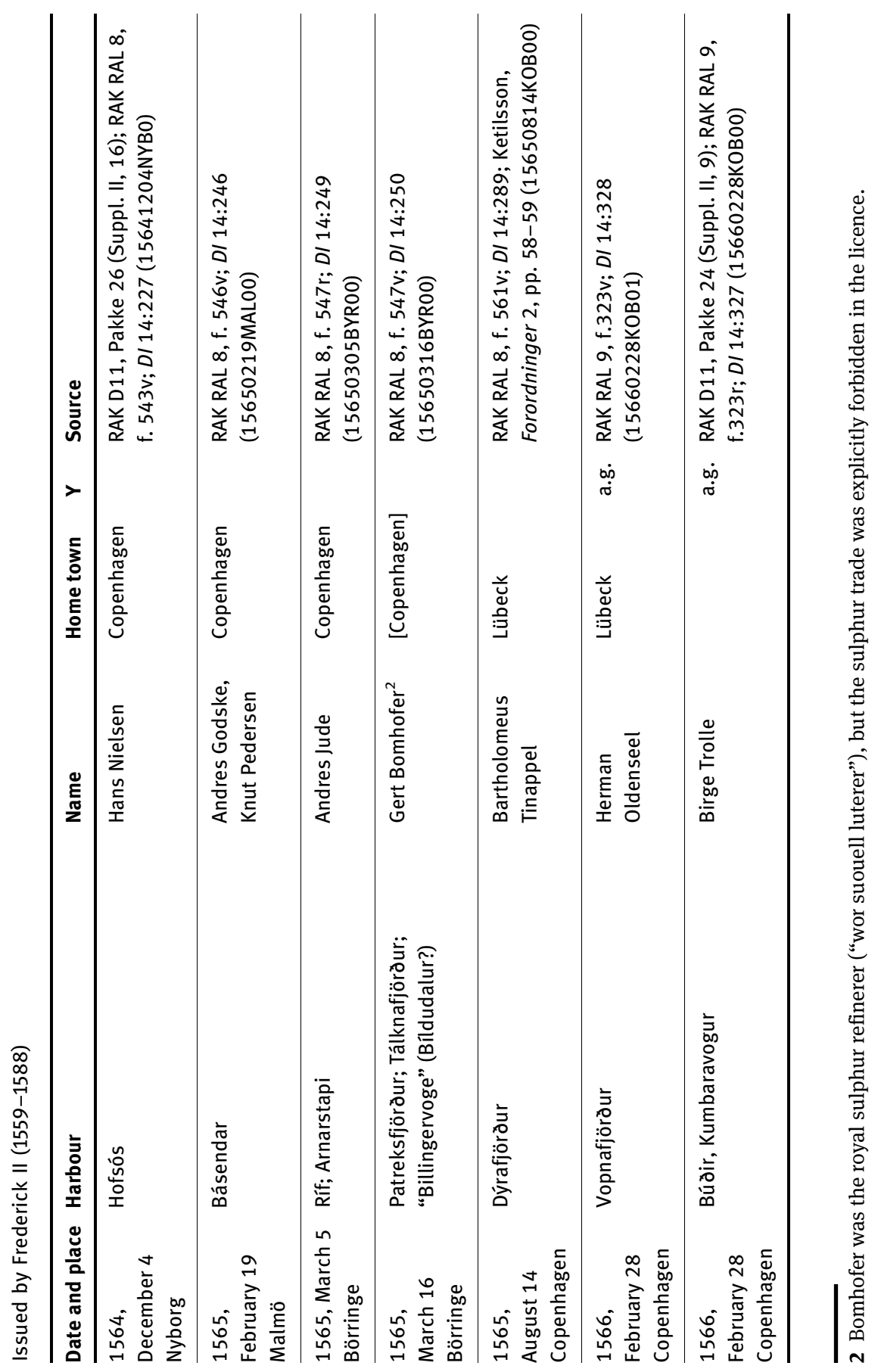




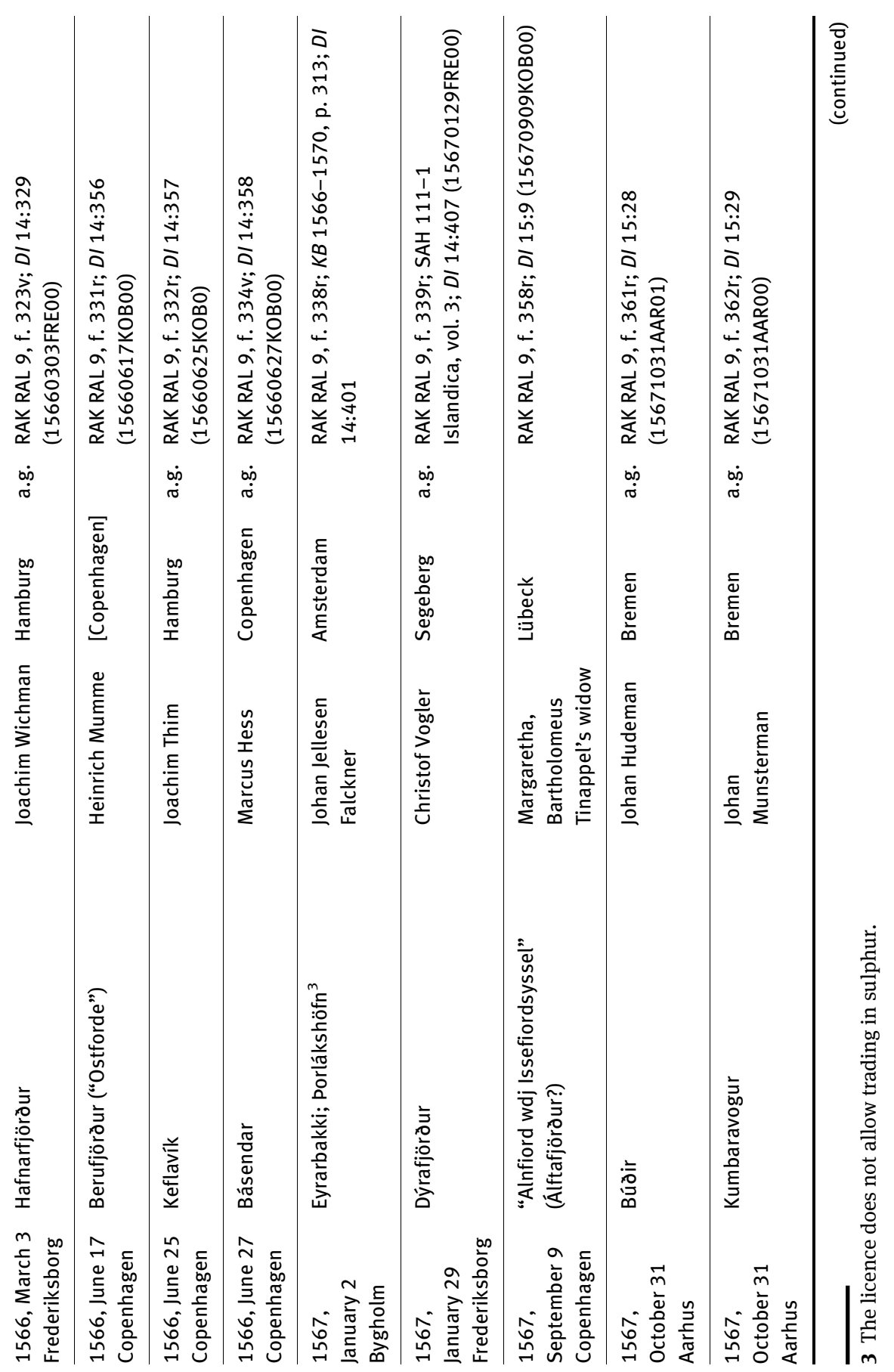




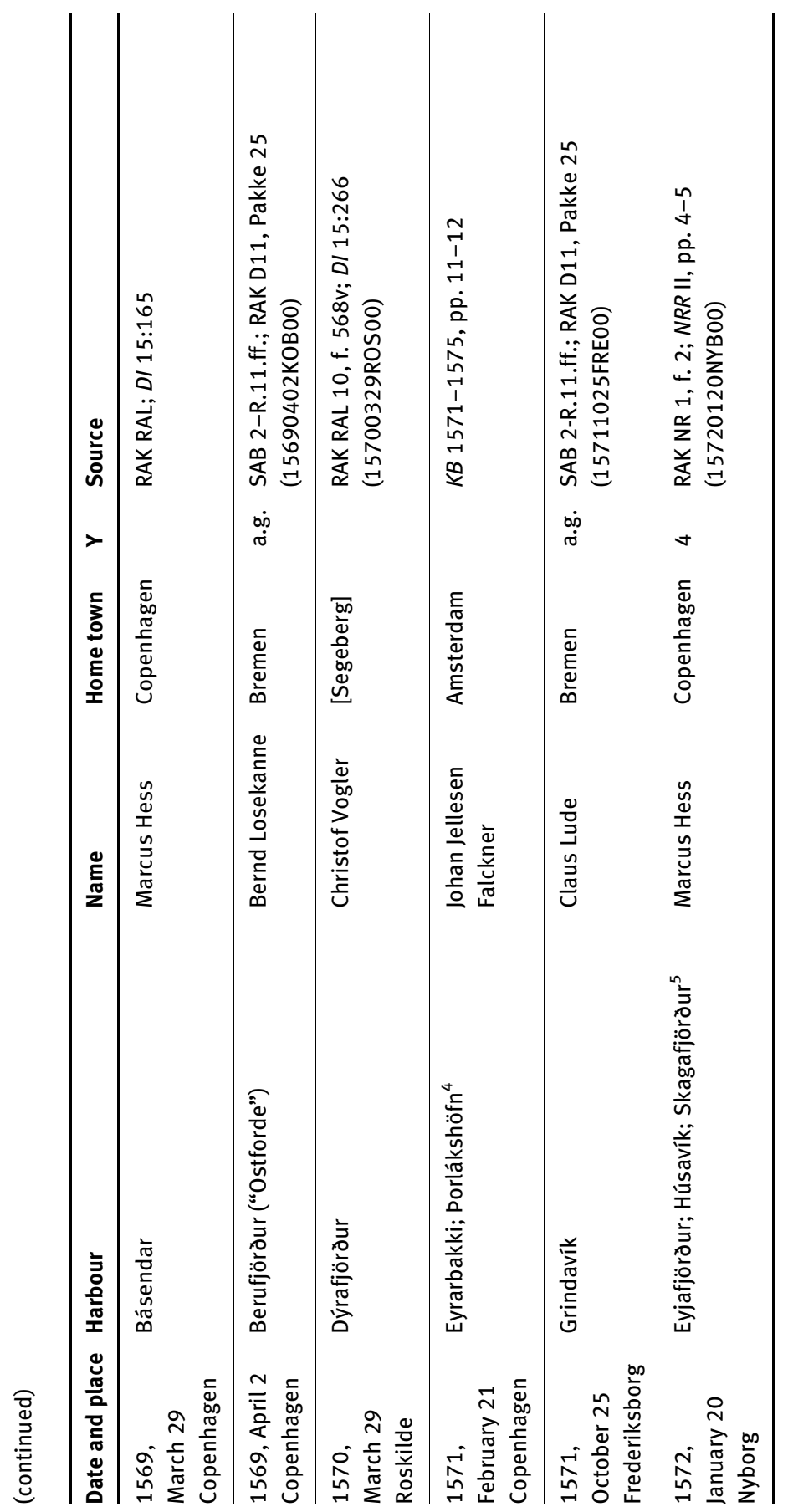

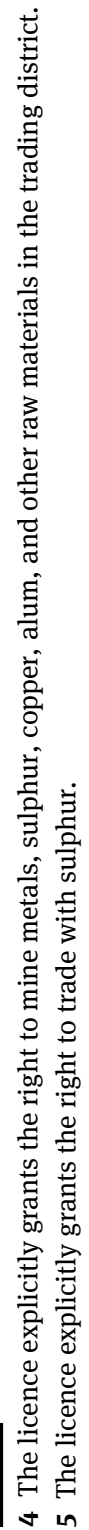




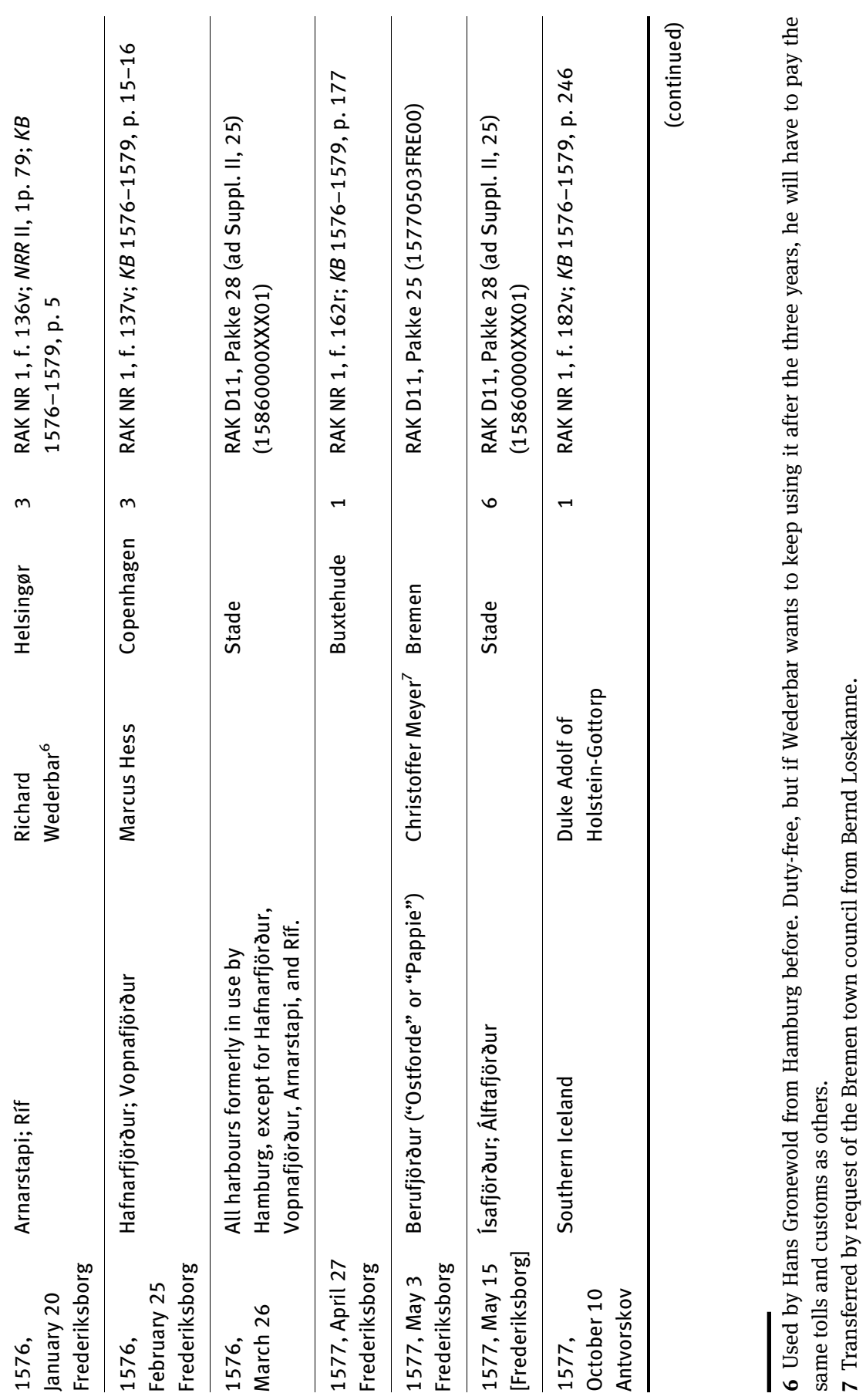




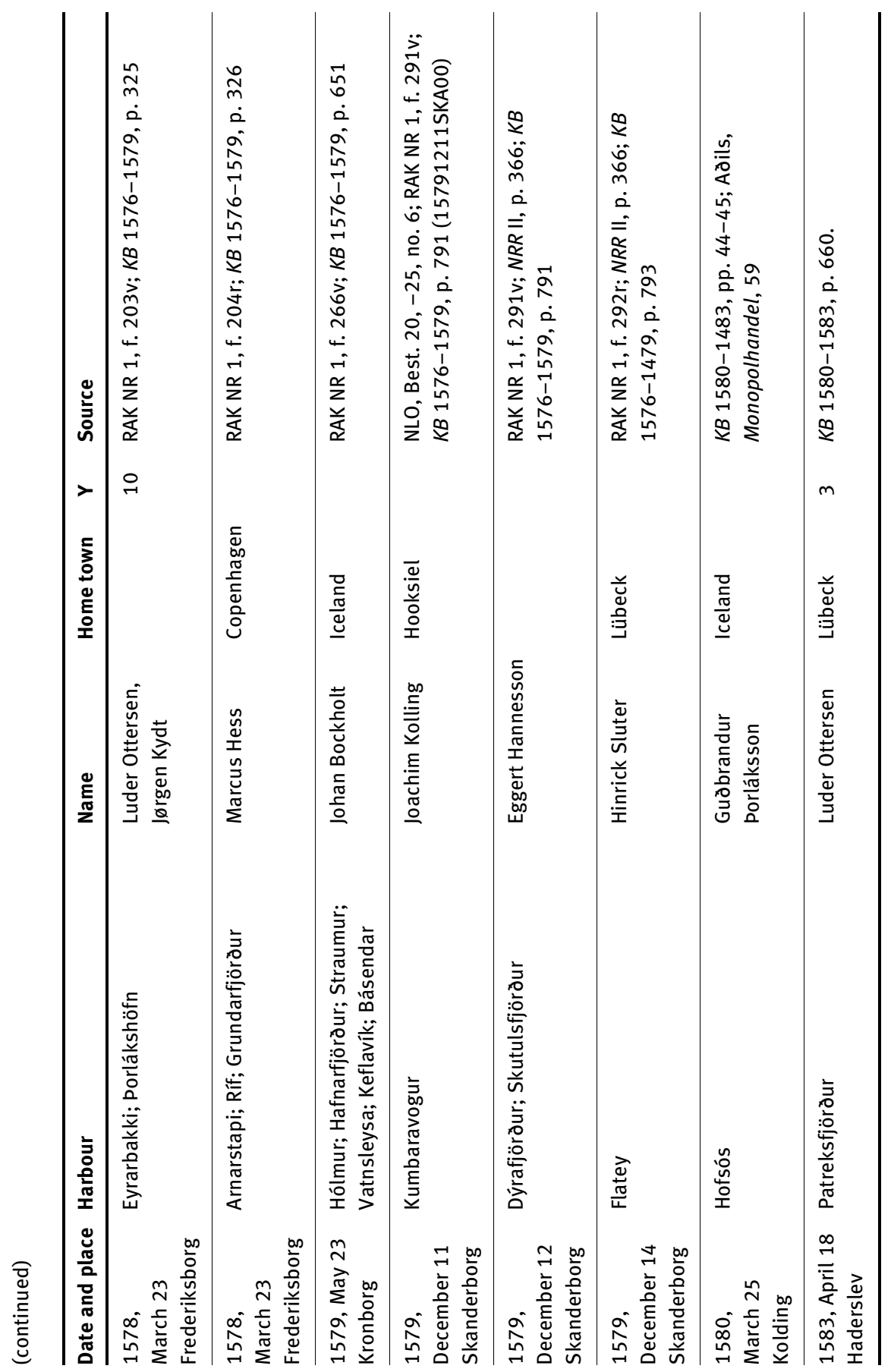




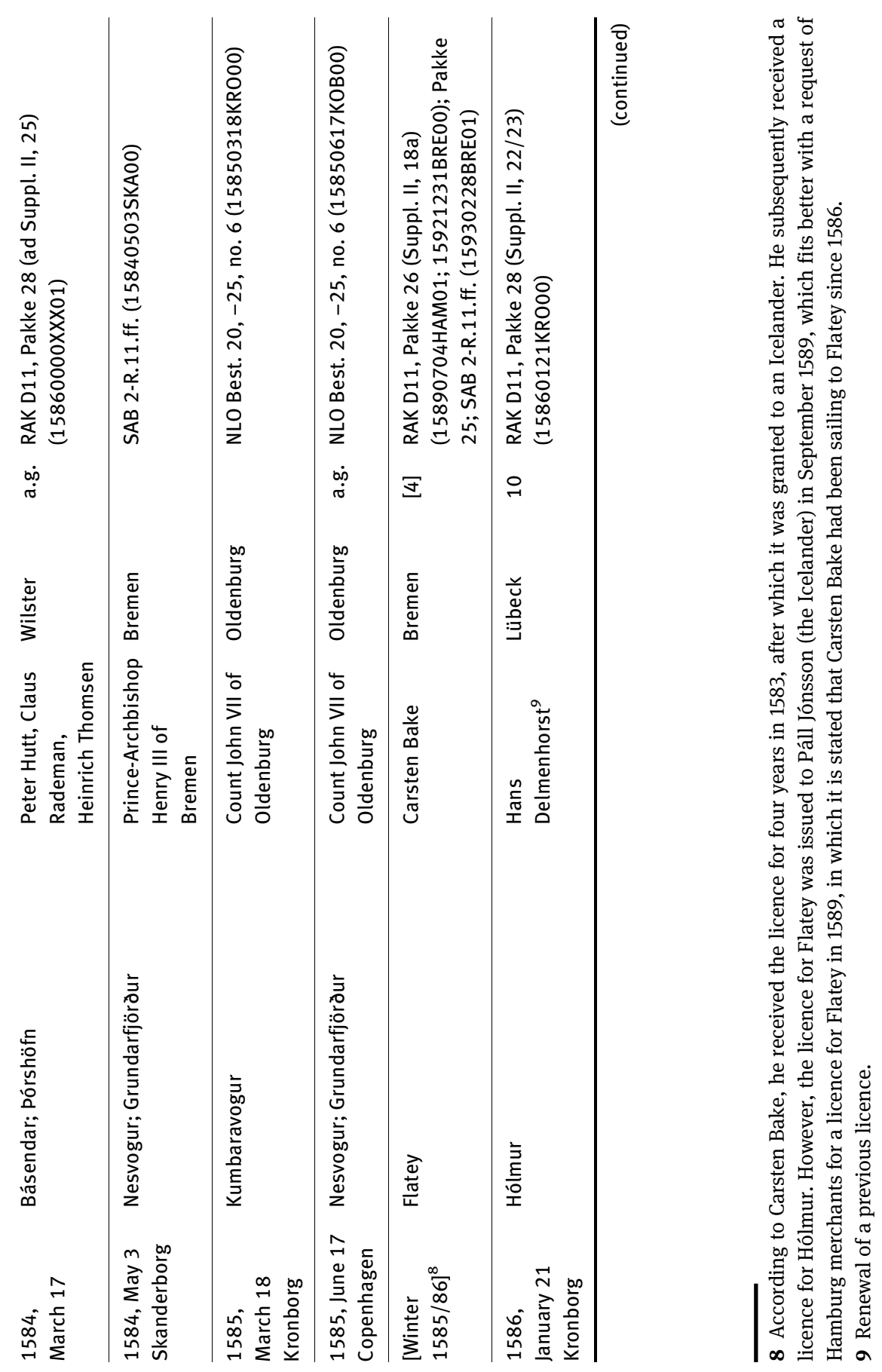




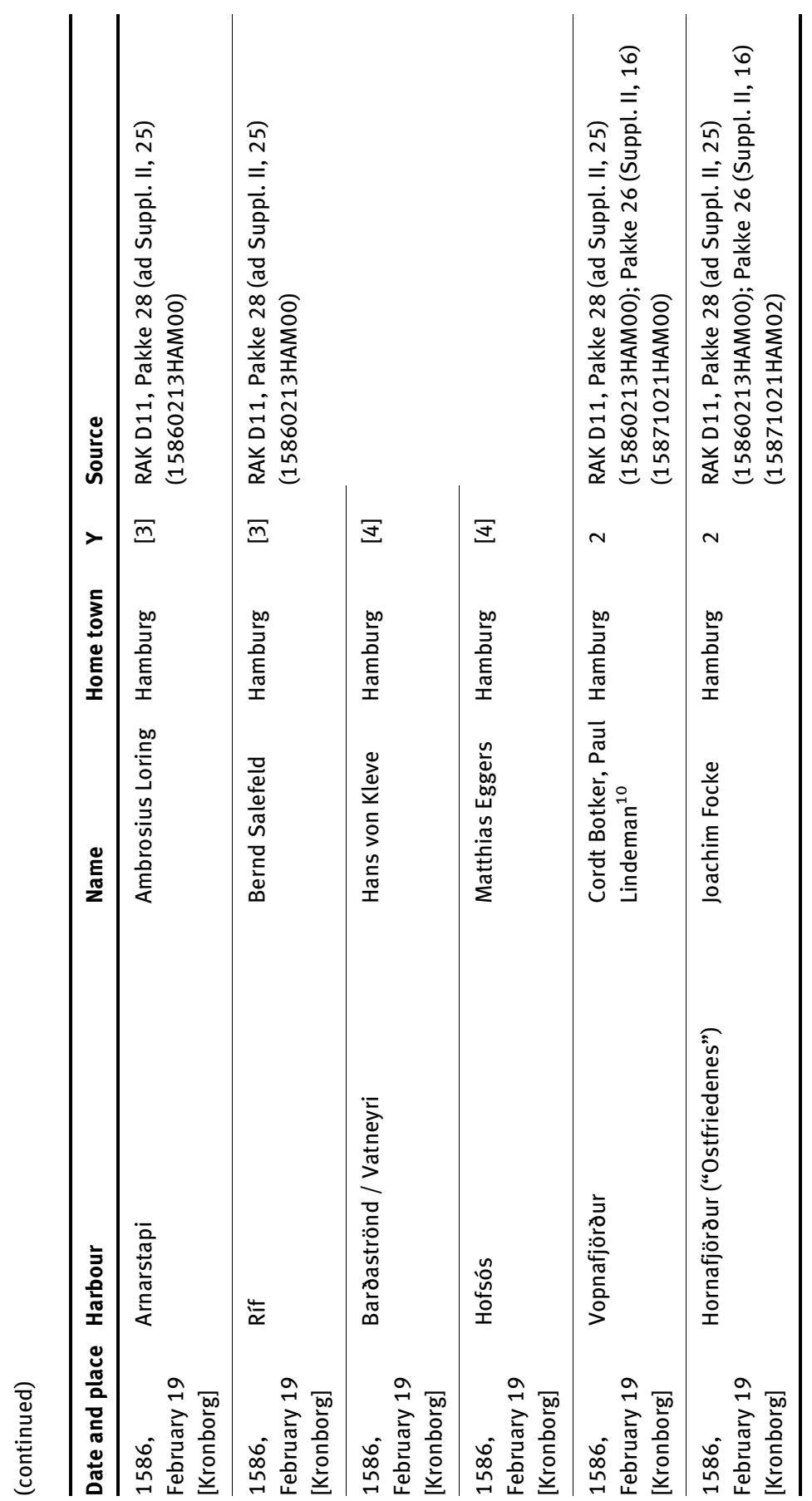

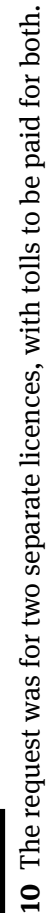




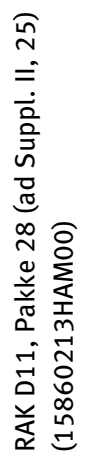

$\Xi$

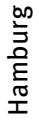

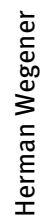

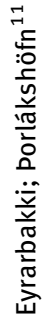

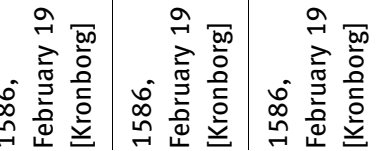

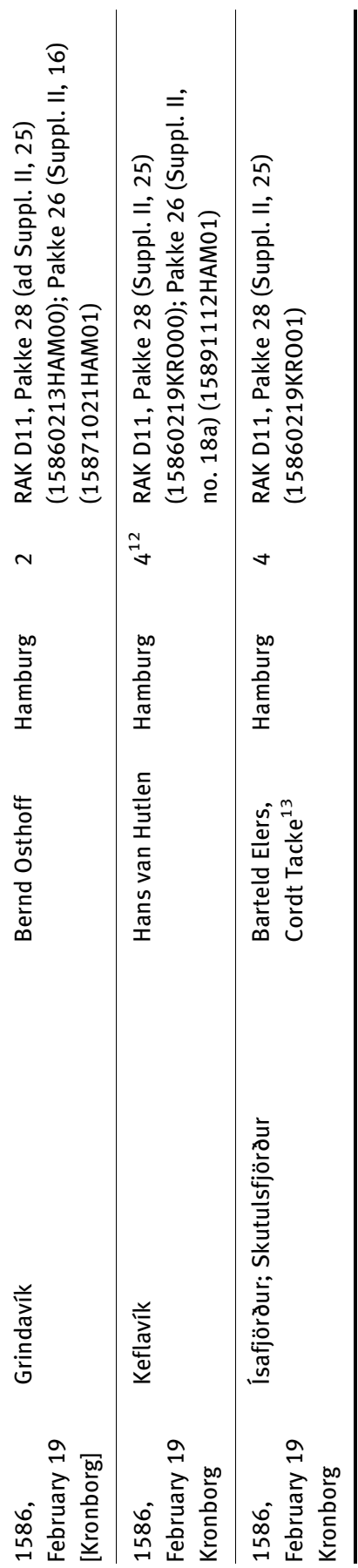

昰

密

$\stackrel{\Xi}{ \pm}$

完

:

$\stackrel{8}{8}$

莺

$\stackrel{n}{\exists}$

密

棄

ฮึ :

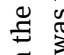

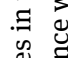

过

$\pi$

表

芒

要

능

氜

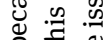
㻤 青㶾 है 范 芴

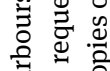

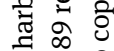

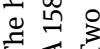
更 4 


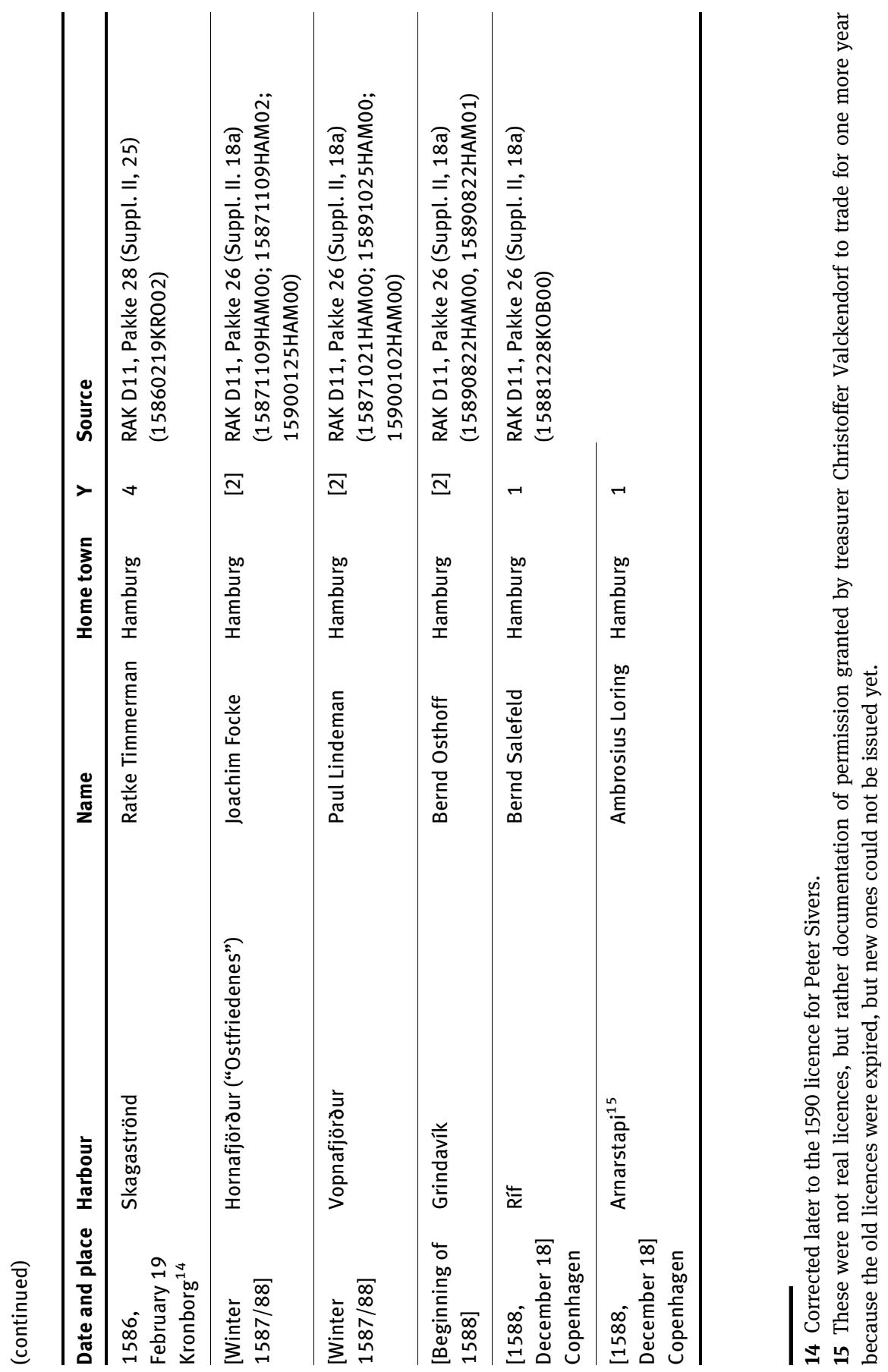




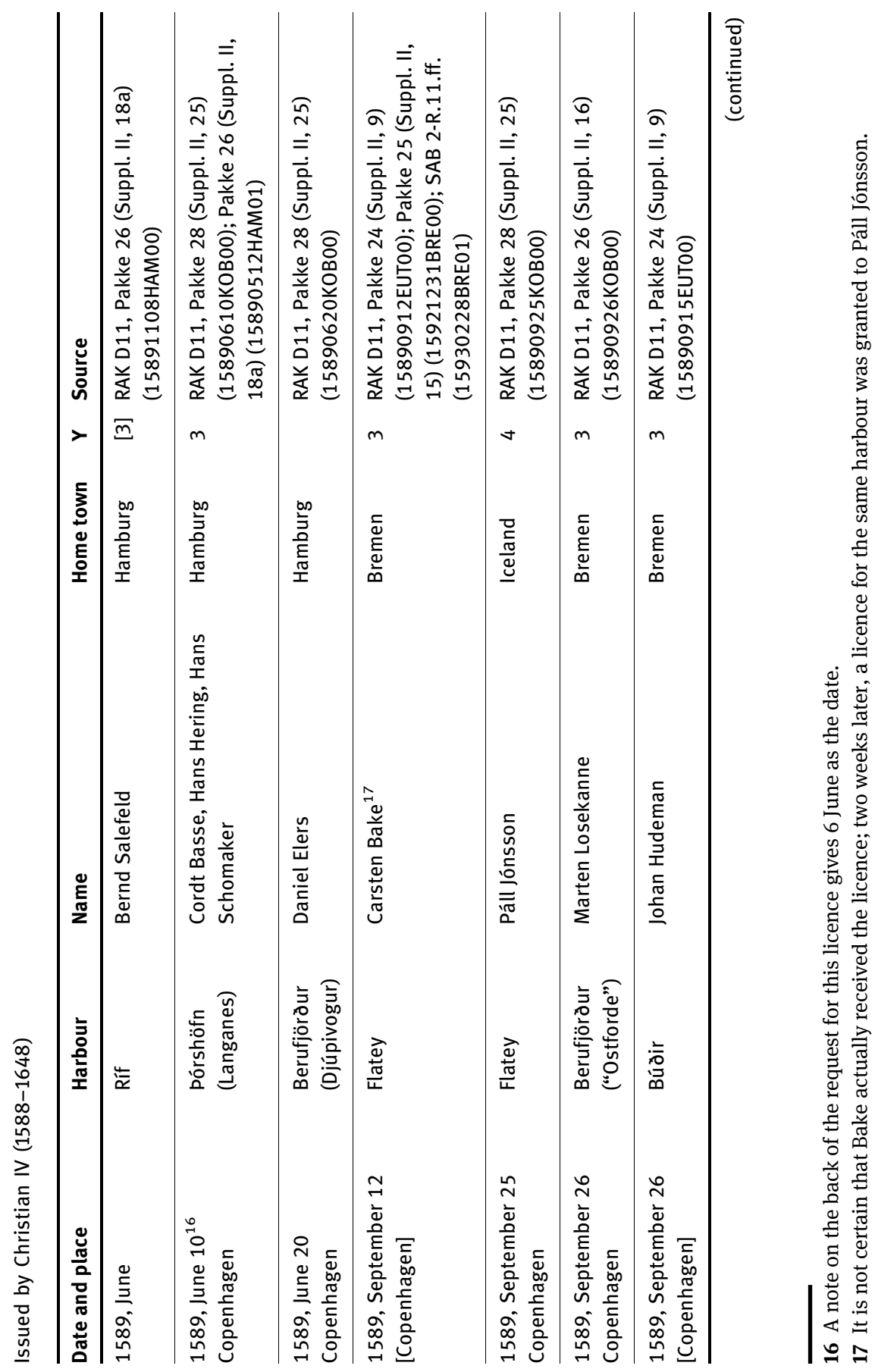




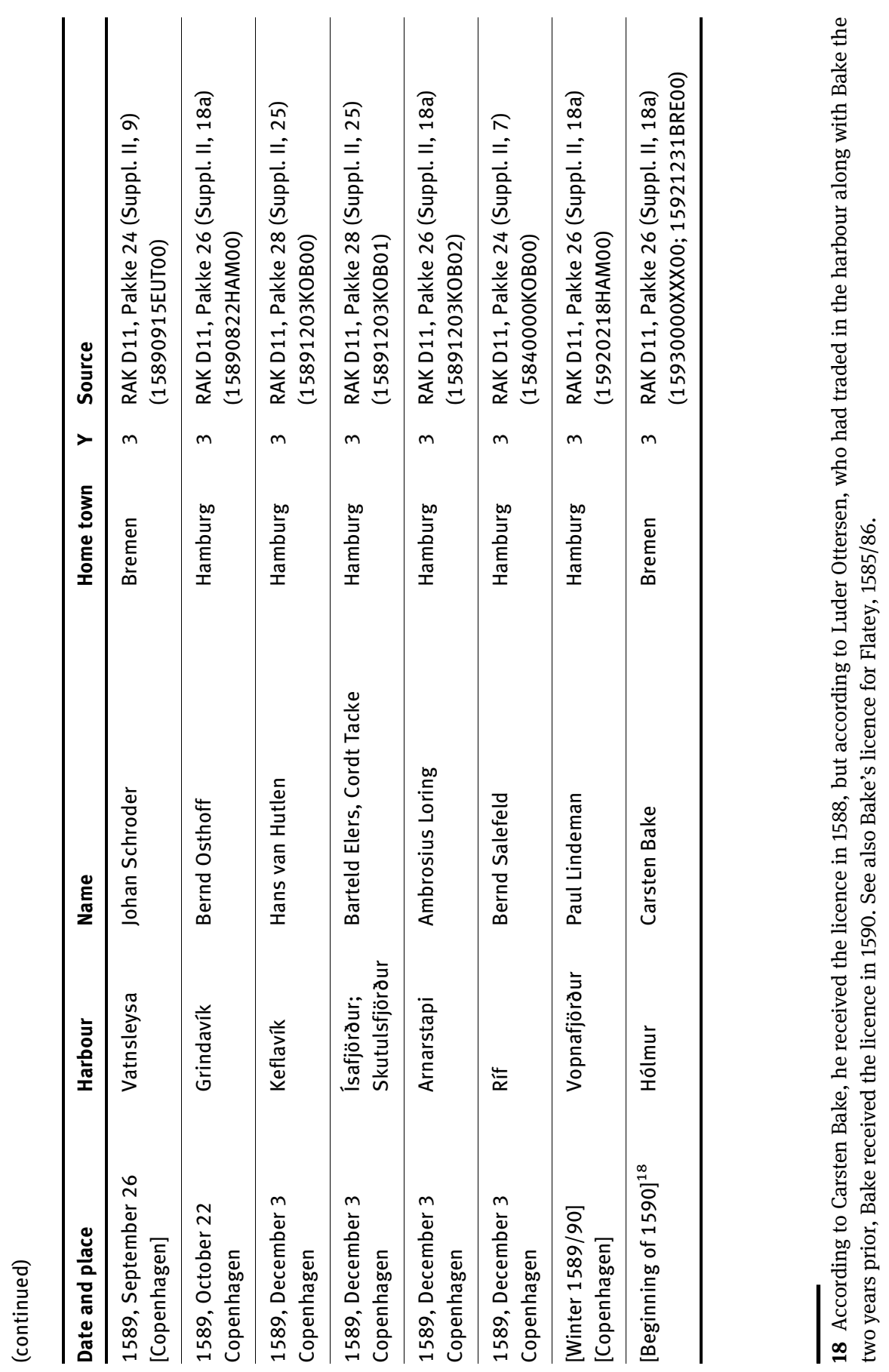




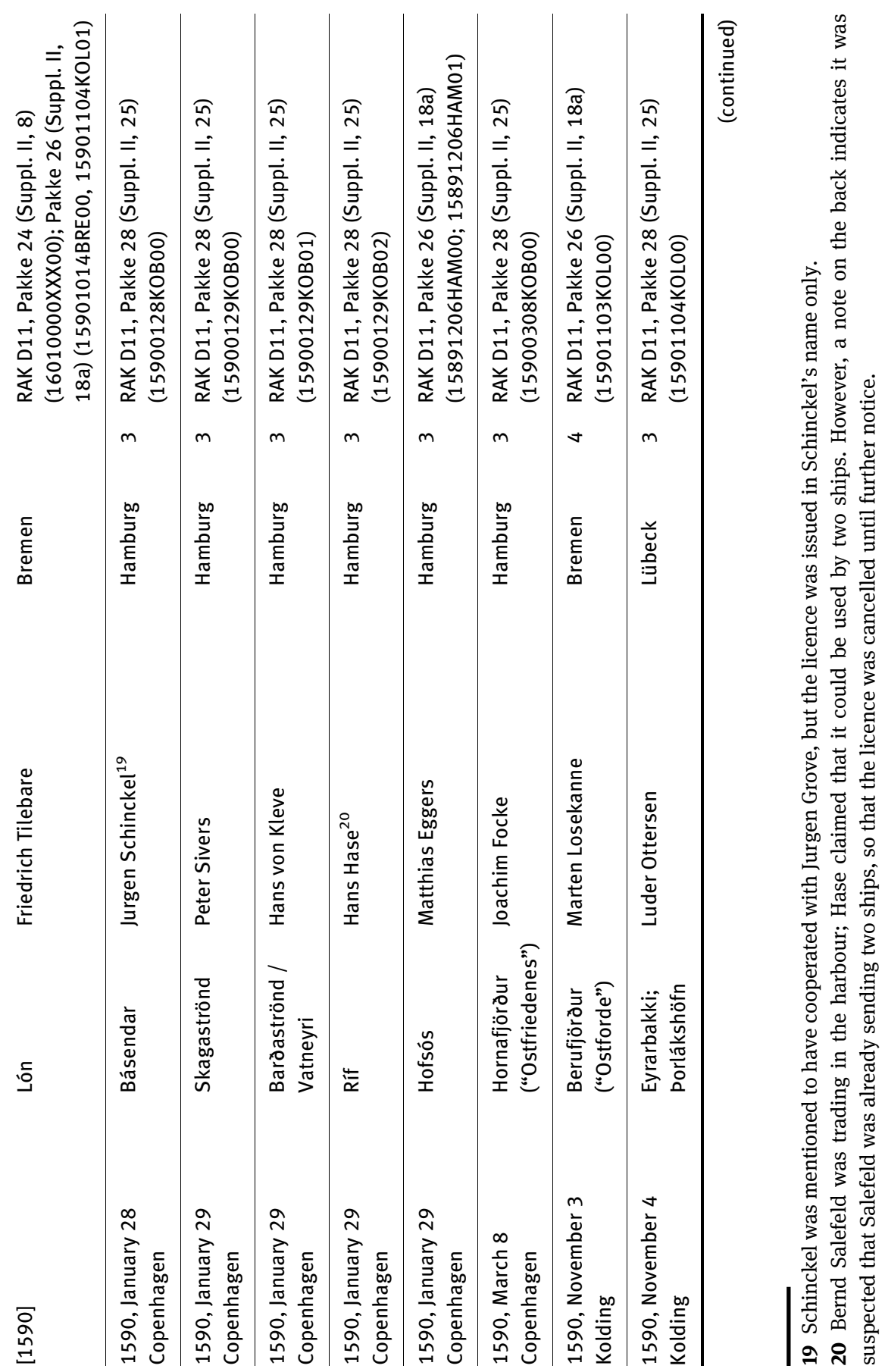




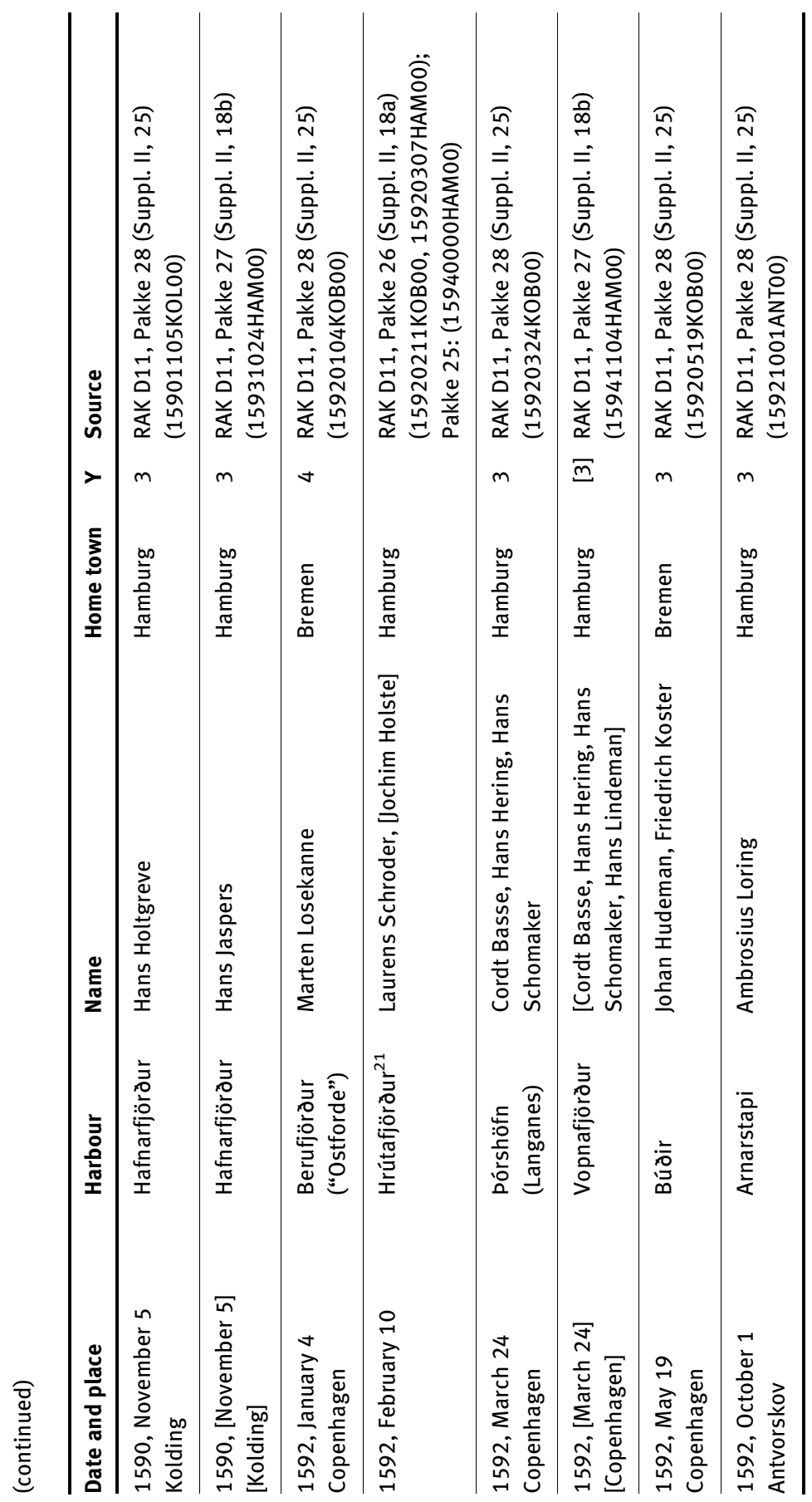

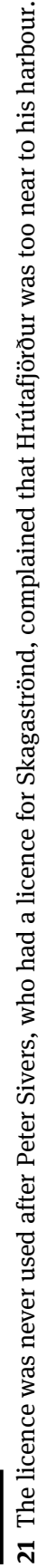




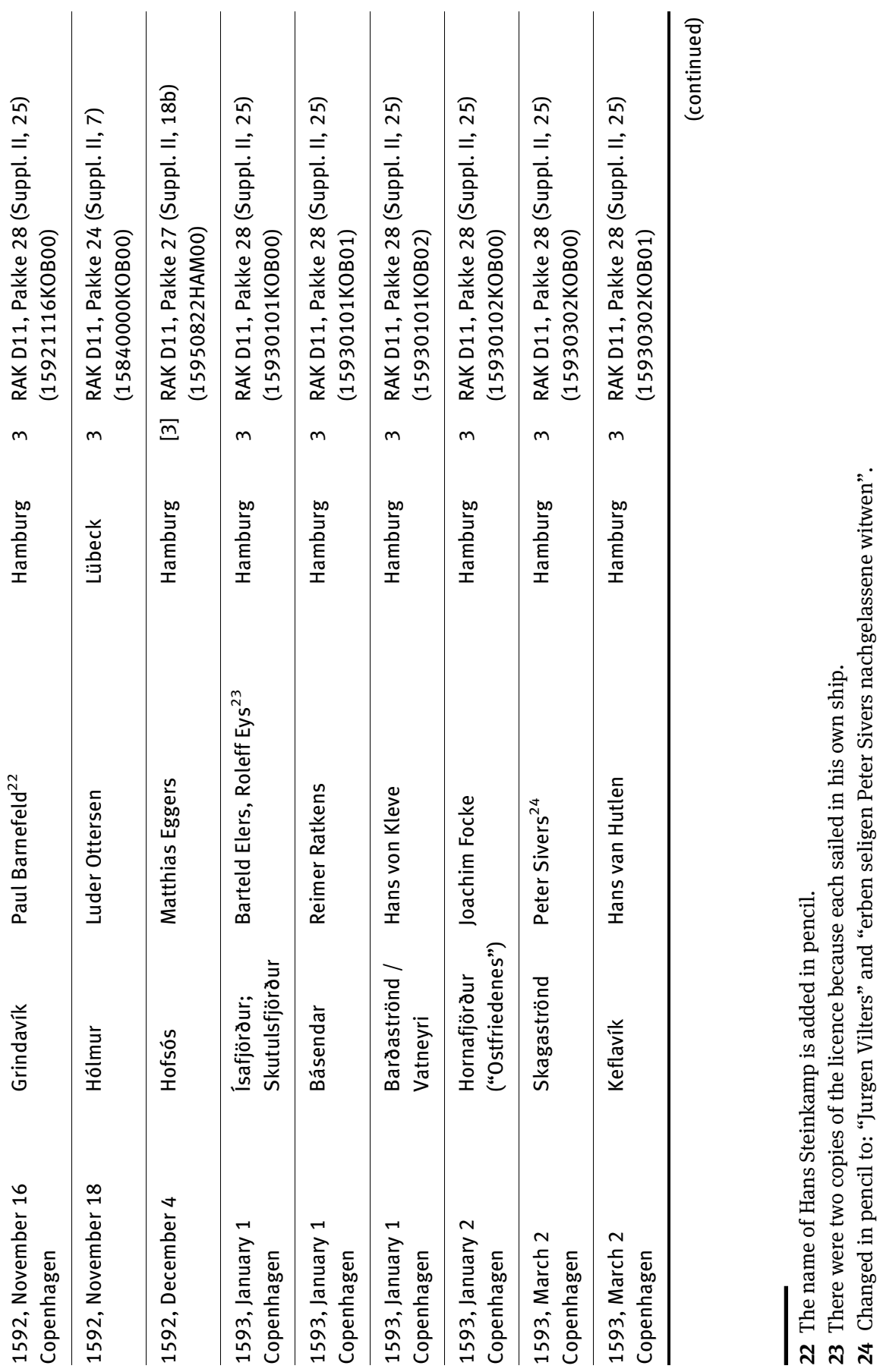




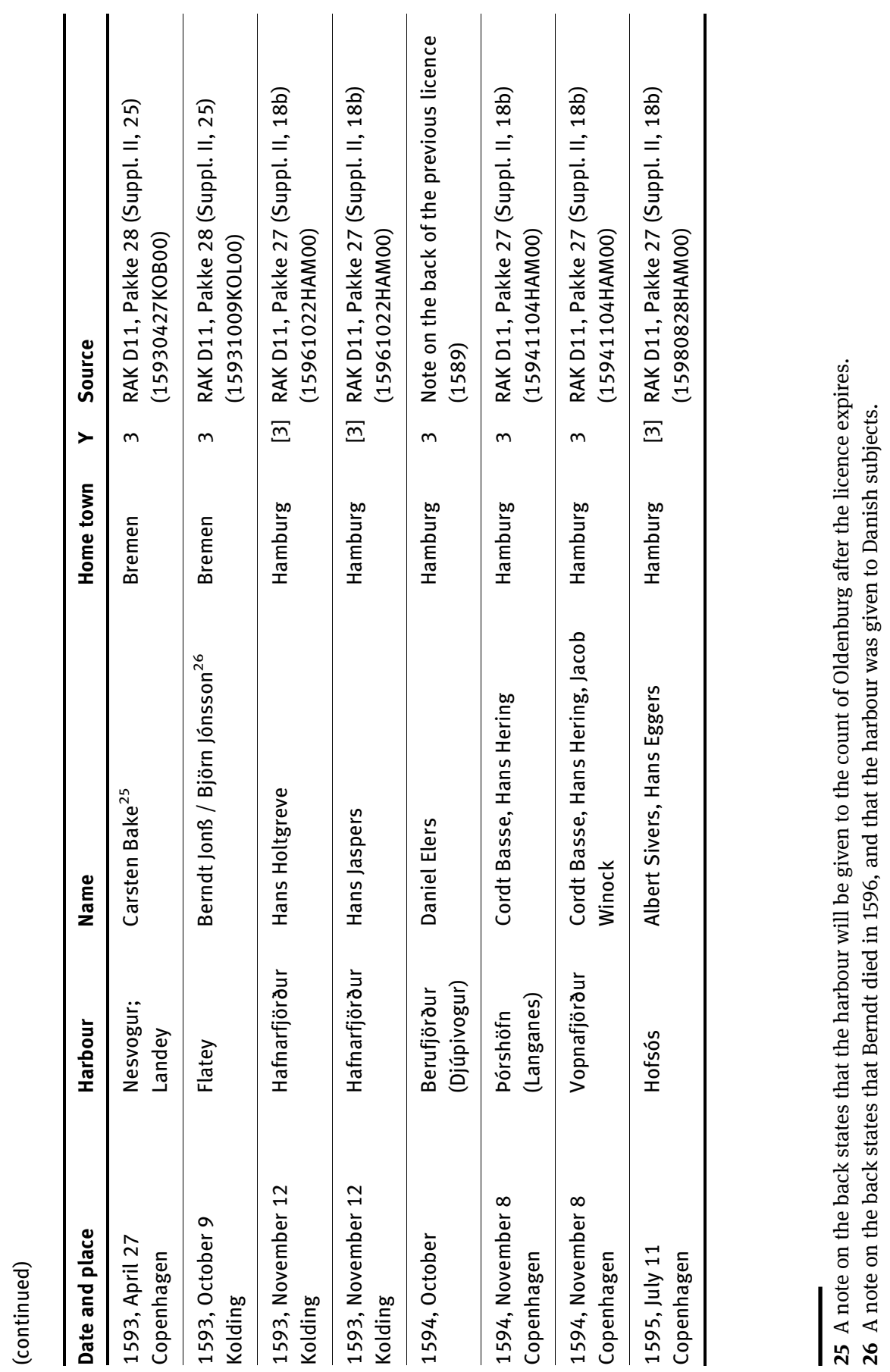




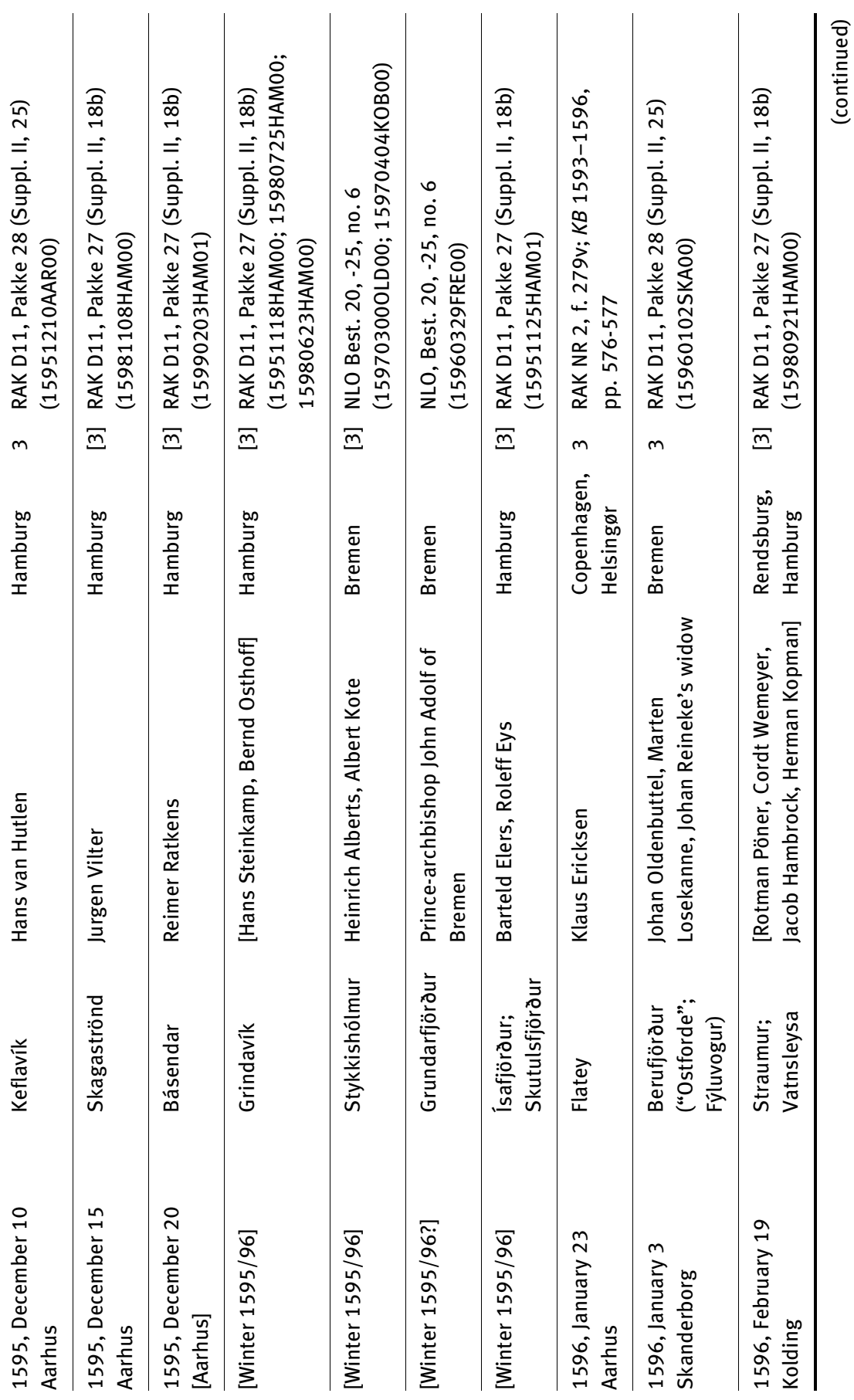




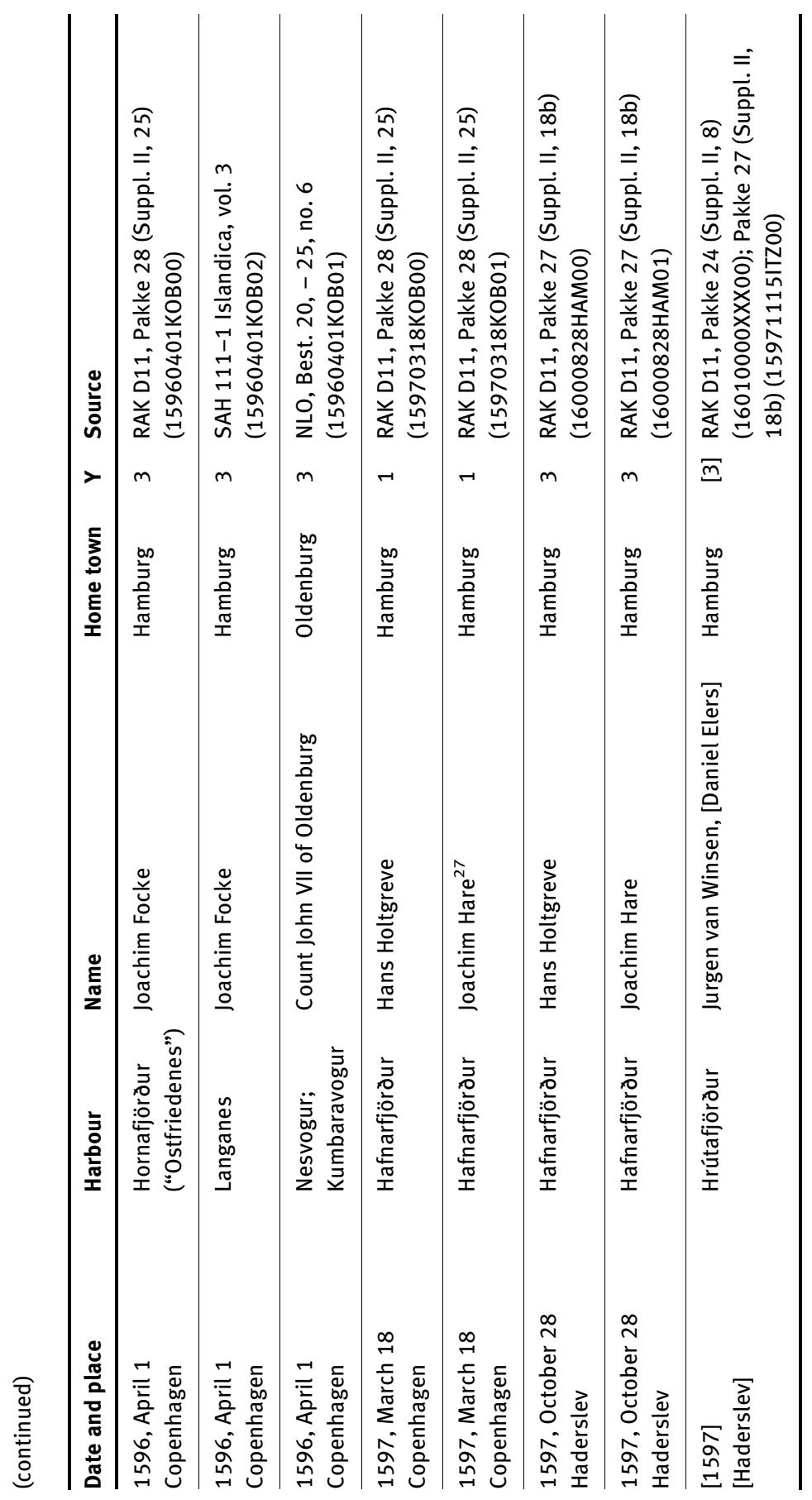

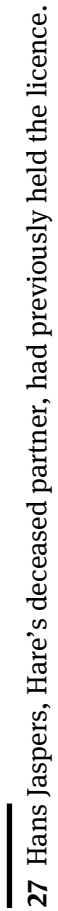




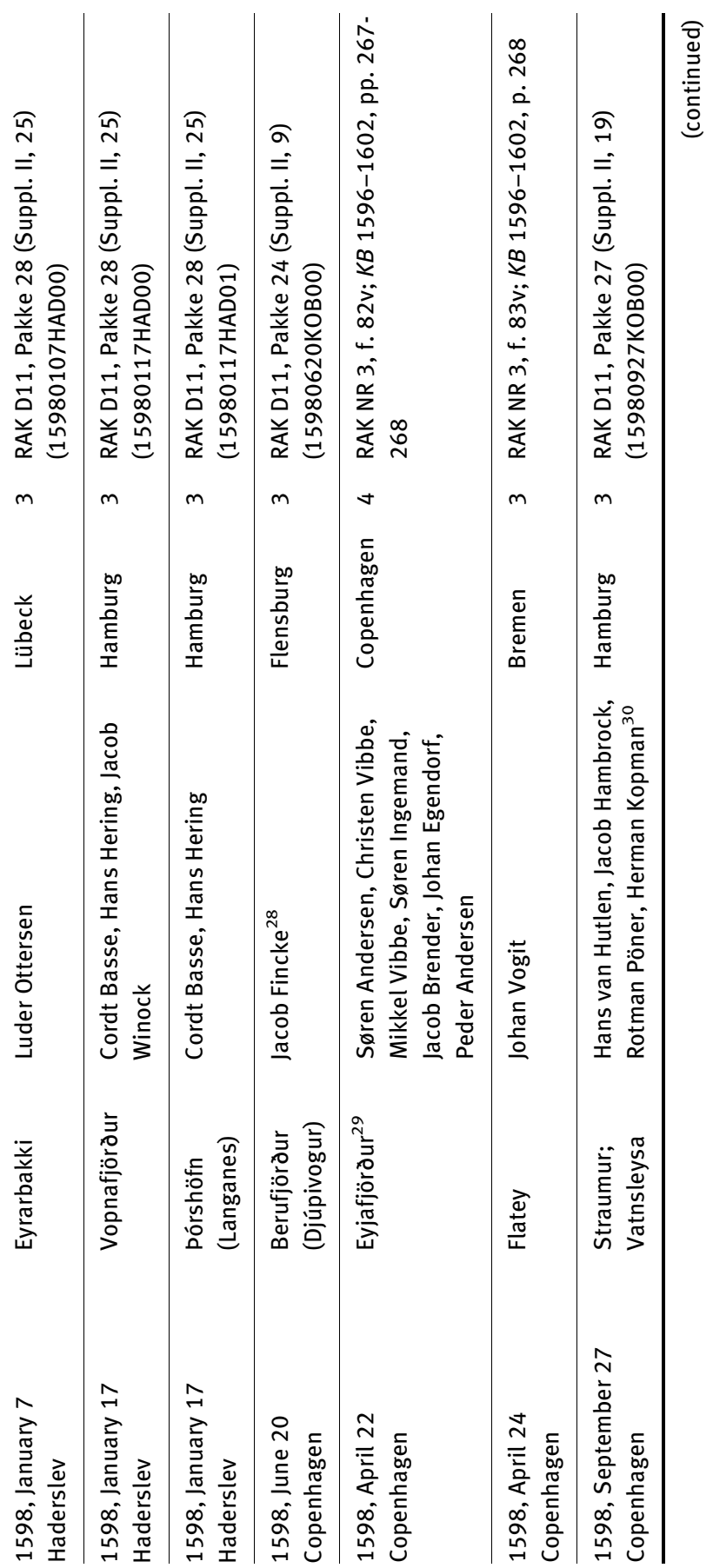

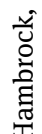

$\therefore$

若

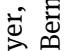

苞

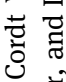

$\operatorname{\omega ic}_{\exists} \frac{\vec{c}}{\overline{0}}$

完

Eี ชี

흘

: :

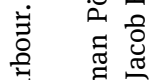

范

声

芯 苗

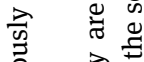

娄

范 起

ซึ.

ॐ

윻휴

अ के

음 $\Xi$

उ ఫ की

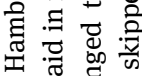

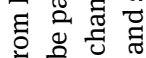

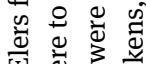

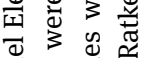

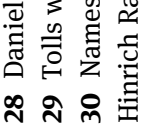




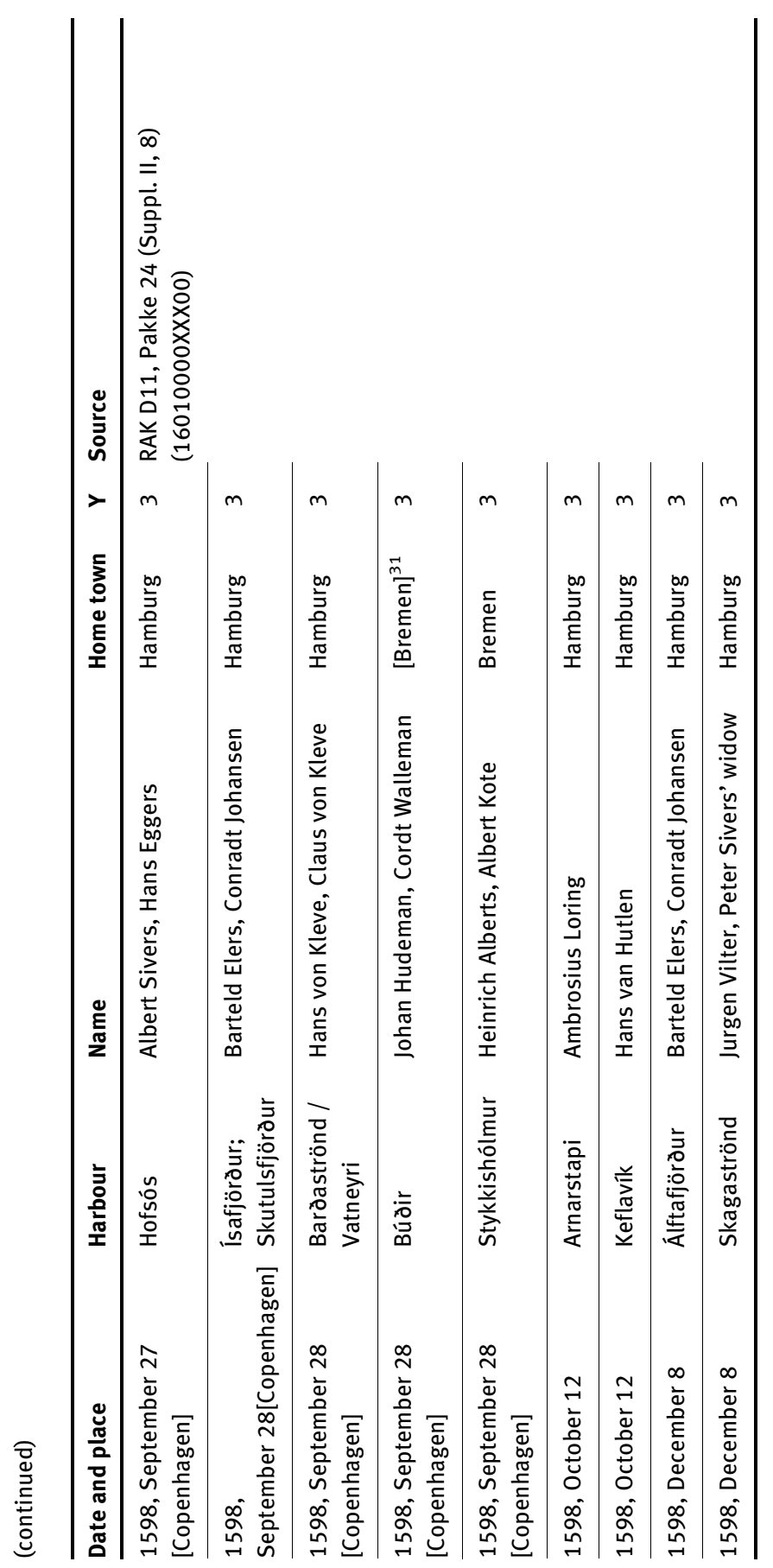




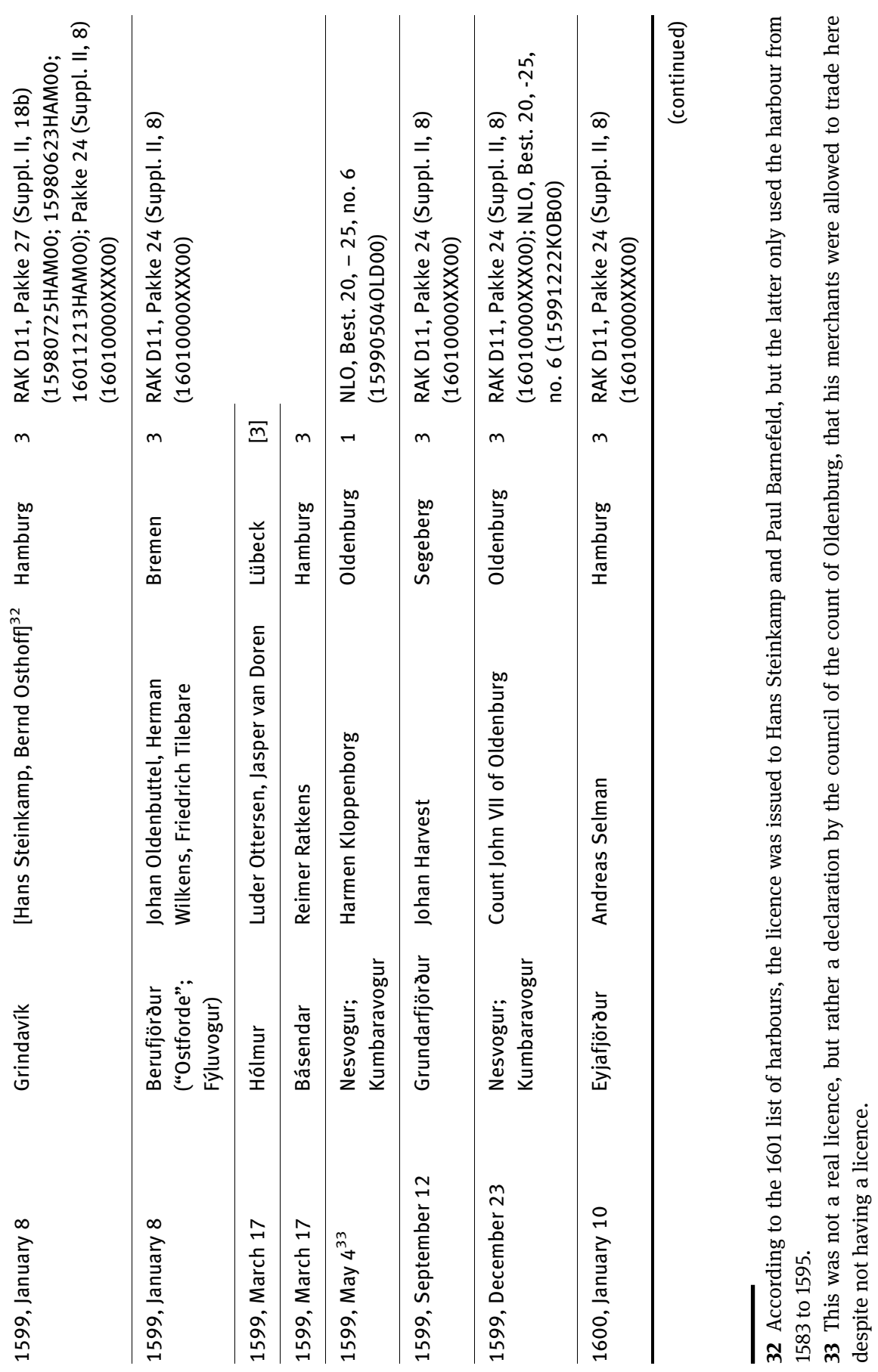




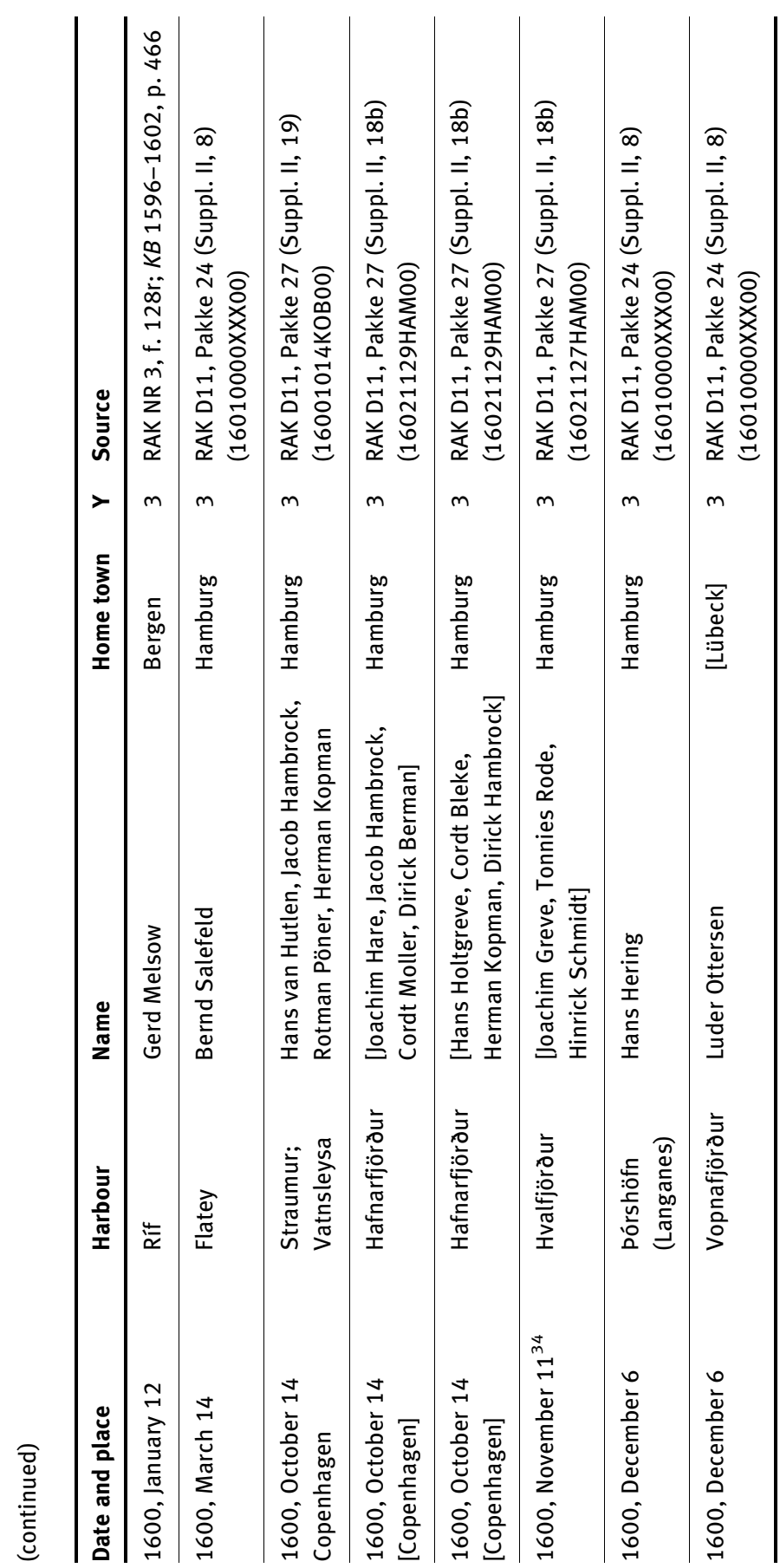

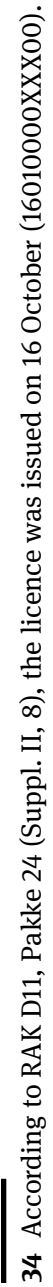

